\title{
Effectiveness of Special Ballistic Exercises on Some Physiological Variables and Developing Explosive Power of Legs and Arms to Improve Skillful Execution in both Floor Exercise and Vault Table for Gymnastics Players *Dr/ Khaled Abuwarda
}

The importance of ballistic training derives from its aim to develop agonists, antagonists, and stabilizer muscles. Ballistic training method doesn't involve any decrease or depression in the speed, so it maintains the specific compatibility of most games. Scientific studies have demonstrated. That ballistic training led to improve muscle capacity. The percentage of improvement higher than plyometric training and the traditional training weights. This study aims to identify the effectiveness of special ballistic exercises on Some Physiological Variables and developing explosive power for legs and arms to improve skillful execution in floor exercise and vault table for gymnastics Players. The research sample was selected by intentional way of game is not intentional of the first-class gymnasts of Suez Canal Authority Club in Port Fouad. The sample of basic experiment included 5 players . The most important results were effectiveness of special ballistic exercises with added in the part of special physical preparation, which applied to the experimental group was more effective than training on Some Physiological Variables (Adrenocorticotropic hormone, lactic acid, and glucose) and developing explosive power for legs and arms to improve skillful execution in floor exercise and vault table for gymnastics Players

Key Words. Ballistic exercises, explosive power, floor Exercise, vault table

\begin{tabular}{|c|c|}
\hline ine & \\
\hline scientific & reach high levels. In order to \\
\hline development & achieve the highest level of \\
\hline methods in gymnastics is a & performance \\
\hline goal sought by the nations of & competition, \\
\hline nowledge and concepts in a & $\begin{array}{l}\text { gymnastics pl } \\
\text { technically }\end{array}$ \\
\hline their coaches & preparation in the light of \\
\hline $\begin{array}{l}n \text { order to setup } \\
\text { evelopment of play }\end{array}$ & $\begin{array}{l}\text { modern requirements to } \\
\text { practice gymnastics. It requires }\end{array}$ \\
\hline
\end{tabular}

-Faculty of Physical Education for Boys and Girls, University of Port Said. Assiut Journal For Sport Science Arts 
a high level of physical and skill competence so that the player can perform the motor duties entrusted to him efficiently.

Ahmed Farouk (2003) defined Ballistic training as "the ability of muscles to perform movements as quickly as possible when the resistors are light, medium, ranging from 30: $50 \%$." While it is defined by Gamal Talaat (2003) that it is a relatively recent training method linking between plyometric training elements and weight training, which includes lifting relatively light weights and at high speeds. [1, 8]

The importance of ballistic training derives from its aim to develop agonists, antagonists, and stabilizer muscles. Ballistic training method doesn't involve any decrease or depression in the speed, so it maintains the specific compatibility of most games. Scientific studies have demonstrated the study conducted by Mceroy K.P Neuten, R. U. (1998) that ballistic training led to improve muscle capacity by $18 \%$ in the vertical jump. The percentage of improvement in plyometric training was $10 \%$, while it was
$5 \%$ of improvement in vertical jump in the traditional training weights. [7] In a study conducted by both Zeher, E \& Sale, D.C. (1994) about "The effect of the ballistic movement on activating the muscle and neuromuscular adaptation", they concluded that the movements performed in maximum velocity acceleration could be considered as ballistic movements characterized by high rates of starting and short contraction times. [20] Ehab Abdul Basir (2000) quoted from "Moskir", indicated that gymnast needs a large amount of the explosive power. It is considered the first factor to success in the skill performance of gymnastics routines. [3]

Bahaa Slama (2008) suggested that the study of physiological variables under the influence of sports activity have a significant importance in order to identify the acquisition amount of player's organs; in addition, to identify their ability to adapt against the exerted effort of sports activity. Physiological information is also one the most important bases that help the coach in in achieving the goals of the 
planning and implementation of his/her training programs as well as upgrading the player's performance to the highest level in the special sports activity. [6]

Both Bahaa Salama (2008) ,Mohammed Allawi, Abu Ela Fattah (2003) and Sameh Shabrawy (2002) indicated that Adrenocorticotropic hormone produced and secreted by cells of the anterior pituitary gland. It is known as corticotropin. This hormone works to alert the adrenal gland to secrete cortisol in in the blood during violent sports activities and helps to speed the metabolism of energy sources in the body. The lactic acid and glucose in blood is also considered an indicator of the extent of progress in sports training and the determination of the player's level. [6,15, 9]

Both floor exercises and vault table are of the most important artistic gymnastics apparatuses for men, which require the player to perform routines containing rotations around the transverse axis of the body and rolls around the longitudinal axis. The difficulty degree of those routines increase depending on the complexity of the required duty motor during the phase of flight, which requires strong take-off with the two legs and pushing with hands. Therefore, the player needs to develop explosive power for both legs and arms to be able to increase his/her height during the phase of flight, which enabling him/her to perform high difficulty routines. This leads to increase in the value of difficulty and thus to increase the value of the score of judges. . Based on the foregoing, it is obvious that there is a need to develop the training programs to develop the explosive power of both legs and arms as a crucial element in improving the output of pushing with both legs and arms.

The ballistic training method is one of the effective methods in training programs for the development of explosive power, which prompted the author to use this method in developing the players' developing explosive power for legs and arms, and to find out the extent of its impact on some physiological variables (Adrenocorticotropic hormone, lactic acid, and glucose) and the improve 
skillful execution in floor exercise and vault table for gymnastics Players

\section{Objective:}

This study aims to identify the effectiveness of special ballistic exercises on Some Physiological Variables and developing explosive power for legs and arms to improve skillful execution in floor exercise and vault table for gymnastics Players

\section{Hypotheses:}

1- There would be statistically significant differences between both pre and post-tests of some physiological variables (Adrenocorticotropic hormone, lactic acid, and glucose)for gymnastics Players of the experimental group and in favor of post-test.

2- there would be statistically significant differences between both pre and post-tests of the variable of explosive power of the two legs, arms for gymnastics Players of the experimental group and in favor of post-test. 3- there would be statistically significant differences between both pre and post-tests of the level of skill performance in the floor exercise and vault table for gymnastics Players of the experimental group and in favor of post-test.

\section{Terms Definitions}

- Ballistic Exercises: are relatively recent exercises linking the elements of plyometric training to weightlifting training, including light weights at high speeds. [14]

\section{- $\quad$ Adrenocorticotropic}

hormone (ACTH): A hormone that is produced and secreted by the cells of the anterior pituitary gland and is known as corticotropin hormone. [6]

\section{Procedures:}

\section{Methodology:}

The author has used the experimental method, using the design of one experimental group (pre-test, post-test).

\section{Sample:}

The research sample was selected by intentional way of game is not intentional of the first-class gymnasts of Suez Canal Authority Club in Port Fouad. The sample of basic experiment included 5 players. Both researchers also used 7 players from outside the basic sample from the same research community to conduct the scoping study.

\section{Data Collection Tools:}


First: Measuring Height: Length has been measured, using Restameter to the nearest $1 \mathrm{~cm}$.

Second: Weighting: Weight has been measured using medical scale to the nearest 1 $\mathrm{Kg}$.

Third: Measuring Skillful Performance Level: The level of skill performance has been measured in both floor exercise and vault table apparatuses (annex 1), using the jury method according to the instructions of the International Arbitration Law certified by the arbitrators of the Egyptian Federation of Gymnastics. [21] Fourth: Explosive power tests: A set of tests has been selected to measure the explosive power to be applied to the research sample. They have been regulated. It has been indicated that validity and reliability and objectivity coefficients are available, and the instructions of these tests have been clearly defined for their application and registration. In addition, tools and apparatuses required to implement those tests have been available to the author (annex 3). [5, 16]

Fifth: Physiological Variables:

The concentration of Adrenocorticotropic hormone has been measured by the withdrawal of blood samples from the sample and has been analyzed in Al-borg laboratory in Port Said, Egypt by private laboratory reagents.

- The ratio lactic acid has been measured, using Akio Sport device to measure the ratio of lactic acid in the blood.

- Glucose has been measured, using One Touch device to measure glucose in the blood.

\section{Training program:}

The researcher set up the proposed training program to develop core stability by reviewing previous studies and both specialized and science sports coaching.

\section{The Pilot Study :}

The researcher conducted the pilot study in the period from Sunday 21/6/2015 to Thursday $2 / 7 / 2015$ in order to ensure the safety and validity of the tools and devices used and ration physical skill preparation exercises and special ballistic exercises in which the training program involved. This was done by using a sample of 2 players from the same research community and outside the basic research sample. 
Basic Experiment:

Pre Tests: Pre-test conducted on basic research sample in the Hall of Suez Canal Authority Club Port Said, In the period

\section{Table (1)}

the significant statistical differences of Wilcoxon test between both pre and post-test in the explosive power and Physiological Variables and skill performance level on floor exercise and vault table for gymnastics Players $n=5$

\begin{tabular}{|c|c|c|c|c|c|c|c|}
\hline \multirow{3}{*}{ Tests } & & \multirow{3}{*}{ unit } & \multicolumn{4}{|c|}{ Control group } & \multirow{3}{*}{$\begin{array}{l}\mathbf{Z} \\
\text { value }\end{array}$} \\
\hline & & & \multicolumn{2}{|c|}{$\begin{array}{l}\text { Average } \\
\text { of ranks }\end{array}$} & \multicolumn{2}{|c|}{ Total ranks } & \\
\hline & & & + & - & + & - & \\
\hline \multirow{3}{*}{$\begin{array}{l}\text { Explosive } \\
\text { power }\end{array}$} & $\begin{array}{ll}\text { Standing } & \text { Broad } \\
\text { Jump } & \\
\end{array}$ & $\mathrm{m}$ & 0.00 & 5.00 & 0.00 & 15.00 & 0.00 \\
\hline & Vertical jump & $\mathrm{cm}$ & 5.00 & 0.00 & 15.00 & 0.00 & 0.00 \\
\hline & $\begin{array}{l}\text { Threw a weight of } \\
900 \mathrm{gm}\end{array}$ & $\mathrm{m}$ & 0.00 & 5.00 & 0.00 & 15.00 & 0.00 \\
\hline \multirow{2}{*}{$\begin{array}{l}\text { Skillful } \\
\text { performance } \\
\text { level }\end{array}$} & Vault Table & Degree & 0.00 & 5.00 & 0.00 & 15.00 & 0.00 \\
\hline & Floor exercise & Degree & 0.00 & 5.00 & 0.00 & 15.00 & 0.00 \\
\hline \multirow{3}{*}{$\begin{array}{l}\text { Physiological } \\
\text { Variables }\end{array}$} & $\begin{array}{l}\text { Adrenocorticotropic } \\
\text { Hormone }\end{array}$ & $\mu \mathrm{g} / \mathrm{dl}$ & 0.00 & 5.00 & 0.00 & 15.00 & 0.00 \\
\hline & Lactic Acid & $\mathrm{mg} / \mathrm{dl}$ & 0.00 & 5.00 & 0.00 & 15.00 & 0.00 \\
\hline & Glucose & $\mathrm{mg} / \mathrm{dl}$ & 0.00 & 5.00 & 0.00 & 15.00 & 0.00 \\
\hline
\end{tabular}

Wilcoxon Tabular value at the level of statistical significance $(0.05)=0$

Table (1) indicates the significance of statistical differences of Wilcoxon Test of the experimental group between both pre and post-tests in the explosive power and skill performance level on floor exercises and vault table apparatuses, where the value is $\mathrm{P}>0.05$ This indicates that there are statistically significant differences between from Monday 6/7/2015 to

Tuesday 7/7/2015.

Presentation and discussion of results: 
The author attributes this notable superiority of the experimental group members in the variables of explosive power of the leg, arms and level of performance skills in both floor exercises and vault table apparatuses to the efficiency of the training program implemented in developing the explosive power of legs and arms. In addition, the experimental group have used specific ballistic exercises because this kind of training contributes to reduce pivot time, especially it has been taken into account in the selection of specific ballistic exercises, under discussion, that the muscular work is similar to that one in both floor exercises and vault table apparatuses. It is one of the most important factors affecting the moral difference in favor of the experimental group in the test. The results of this research are consistent with those concluded by Hossam El Araby (2010), Ahmed Farouk (2003), Talaat Gamal (2003), Michael Mceroy et al. (1998) K.P. Neuten, R. U. (1998), Bradley and Portas ( 2007).The results of their studies indicated that the ballistic exercises effectively contribute to the development of explosive power. [18, 1, 21, 17, 14,7]

Table (1) indicates has improved in the Physiological Variables between both pre and post-tests ,The author attributes the decline in Adrenocorticotropic hormone in the post-test the experimental group undergoing to the proposed training program, including ballistic exercises, which specializes in developing distinctive speed, and correct rationing of training load components. All these procedures had a positive effect on the physical fitness and players' physiological efficiency, and contributed to ease the nerve pressure on Hypothalamus, which led to lack of secretion Adrenocorticotropic hormone. These results are consistent with those concluded by Gayton and Hall (2006), and Raff and Findling (2003). $[5,24]$

The author attributes the decline in the proportion of lactic acid in the post-testas a result of the high level of players training status from the proposed training program what it is contained of ballistic exercises. This is what 
confirmed by Nader Shelby, 1995, quoted from Lamp as ballistic training increases the size and number of mitochondria, which works to increase the ability of producing three-adenosine phosphate. This is due to the activity of enzymes of Krebs cycle as well as the electron transport system. These changes will, therefore, lead to less production of lactic acid by trained muscles compared to the least training muscles. [23]

The author attributes the lack of glucose concentration in the post-test to the response to the allocated training program as the Glucose is the main source for the construction of energy production units in the human body. The body produces these units to provide the needs of physical effort. Thus, the body provides glucose in anticipation of the physical exertion and satisfies its needs. This explains the lack of the glucose level in blood due to the high physical and physiological level of players. The results of this study are consistent with those of Sameh Shabrawy (2002). [9]

\section{Conclusions:}

the effectiveness of special ballistic exercises with added in the part of special physical preparation, which applied to the experimental group was more effective than training on some physiological variables(adrenocorticotropic hormone, lactic acid, and glucose) and developing explosive power for legs and arms to improve skillful execution in floor exercise and vault table for gymnastics Players

\section{Recommendations:}

- Similar Researches should be conducted on different age stages in gymnastics.

\section{References:}

1- Ahmad Farouk. (2003). The Impact of the Ballistic Training Program on Some Physical and Skill Variables of Basketball Players, the Scientific Journal, Helwan University, Faculty of Physical Education.

2- Aml Riad. (2002). The Effect of Plyometric Exercises on Developing Explosive Power of the Arms and Legs and the Skill Performance Level on Vault Table, the scientific journal, Physical Education College in Port Said, 
Suez Canal University, the fourth issue.

3- Ehab Adel Abdul Basir. (2000). The Effect of the Development of Relative Muscle Strength and Flexibility of Shoulders and Hips Joint on Vault Table, unpublished Ph.D. thesis, Faculty of Physical Education in Port Said, Suez Canal University.

\section{4- Arthur C. Gayton \& Jhon}

E. Hall: 2006، Text boook of medical physiology, Eleventh edition , Elsevier saunders, USA Elsevier Inc.1600 John F. Kennedy Blvd., Suite 1800 Philadelphia, Pennsylvania 19103-2899

5- Bastawisy Ahmed. (1999). The Principles and Theories of Sports Training, Dar al-Fakr Al-Arabi.

\section{6- Bahaa Eddin Salama.} (2008) Physiology of Sport and Physical Performance, Blood Lactates. Dar Al-Fekr AlArabi, Cairo, 216-218, 122.

7- Bradley, P. S., Olsen, P. D., \& Portas, M. D. (2007). The effect of static, ballistic, and proprioceptive neuromuscular facilitation stretching on vertical jump performance. The Journal of Strength \& Conditioning Research, 21(1), 223-226.
8- Talaat Gamal. (2003). The Impact of Using Ballistic Resistance on Some Physical and Skill Variables of Basketball Players, Master Thesis, Helwan University, Faculty of Physical Education.

9- Sameh Shabrawy. (2002). "The impact of a Training Program Using Both Shitō-ryū and Shotokan Methos onSome Physical and Physiological variables of Juniors from 6-8 years in Karate Sport". PhD, Faculty of Physical Education for Boys, Port Said, Suez Canal University.

\section{0- Sdeek Mohammed}

Toulon. (1990). The Impact of the Development of the Distinctive Speed to Improve the Performance of Some Jumping Routines in gymnastics, unpublished Ph.D. Thesis, Faculty of Physical Education for Boys in Alexandria, Helwan University.

11- Adel Abdul Basir. (1999). Sports Training and Integration between Theory and Application, 1st edition, The center of book publication, Cairo.

12- Essam Abdel-Khalek. (2005) Sports Training, Theories and Applications, 
12th edition, Mounsha AlMa'rf, Alexandria.

13- Aweys Jabali. (2000). Sports Training, Theory and Application, 1st edition, Dar GMS . For publication.

14- Ali Talaat. (2003). The Impact of Using Resistors of Ballistic Exercises on Some Physical and Skill Variables of Basketball Players. Master Thesis, Faculty of Physical Education for Boys, Al-haram, Helwan University, pp: 13.

\section{5- Mohammed Allawi, Abu} Ela Fattah. (2003). Physiology of Sports training. Dar Al-Fekr Al-Arabi, Cairo, pp: 212, 44-49.

\section{6- Mohamed Sobhy} Hassanein. (1995).

Measurement and Evaluation in Physical Education and Sports, 1st part, Dar al-Fakr Al-Arabi, Cairo.

17- Mustafa Hashim. (2005). A Comparative Study of the Impact of Using Plyometric and Ballistic training on Some Physical and Skill Variables of Basketball Player. Unpublished Master Thesis, Faculty of Physical Education for Boys,
Al-haram, Helwan University, pp: 12 .

18- Michael $H$, stone, stevns , plisk , Margaret E . stone, brain K. schilling, Harolds . $\mathrm{O}$, brgant, and kyle $\mathrm{C}$. pierce :1998, Athletic Performance development, strength and conditioning, Volume 20 number 6 , Decmber, P .25

19- Michael Kent :1998, The oxford Dictionary of sports and medicine" , Oxford university press

20- Mceroy - K.P Neuten, R . $\mathbf{U}: 199 \wedge$, Baseball throwing speed and base running speed the effect of ballistic aesistance training " : research journal of strength an cobditioning,

21- Hossam El Araby ,2010,The Effectiveness of Using the Ballistic Training for Developing the Muscular Ability On the Strength and Accuracy of High-jump Shooting upon Handball Players" World Journal of Sport Sciences 3 (S): 572-577, ISSN 2078-4724 IDOSI Publications,

22- International Gymnastic Federation :2009, Men's Assiut Journal For Sport Science Arts 
Technical Committee, Code Of

Points For Men's Artistic Gymnastics Competi-tions At World Championships, Olympic Games Regional And Intercompetitions Event With Inter-national Participants.

23- Nader Shelby. (1995). The Development of Physical Efficiency and Its Impact on Some biochemical Variables and Energy Production Systems for Soccer Players. MA, Faculty of Physical Education for Boys, Port Said, Suez Canal University, pp: 139.

24- Raff, H., \& Findling, J. W. :(2003). A physiologic approach to diagnosis of the Cushing syndrome. Annals of Internal Medicine, 138(12), 980-991.
25- Yasser Ashour. (1999). The Effect of the proposed training program to develop the muscle capacity of the arms on the performance level of front somersault skills on Floor Exercises Apparatuses in gymnastics, Unpublished Master Thesis, Faculty of Physical Education for Boys in Cairo, Helwan University.

\section{WEB Sites:}

http://www.fig-

gymnastics.com/

http://www.usa-

gymnastics.org/

http--

www.egyptgymnastics.comresults.

http://www.livestrong.com/arti cle/466118-ballistic-exercises/ http://www.iraqacad.org/Lib/at heer/atheer5.htm 